\title{
\#WelcomeRefugees: A Critical Discourse Analysis of the Refugee Resettlement Initiative in Canadian News
}

\author{
Manar Mustafa ${ }^{a}$ \\ manar355@hotmail.com \\ International Islamic University Malaysia \\ Zahariah Pilus \\ zahariahp@iium.edu.my \\ International Islamic University Malaysia
}

\begin{abstract}
This study focuses on the frames utilized in the depiction of Syrian refugees and social and political actors involved in the Syrian resettlement in Canadian online news media. The role of the media is vital in portraying Syrian refugees' image and affects how the Canadian public perceives them. This paper focuses on utilizing the referential and predicational strategies introduced by the Discourse-Historical Approach (DHA) in framing the Syrian refugees, Liberal government, Conservative party, Canadians, and Canada (henceforth social and political actors). This study examines a total of 31 articles selected from three of the most visited Canadian news sites, namely, the Toronto Star, the Toronto Sun, and the National Post. News articles were collected beginning from the arrival of the first group of refugees in December 2015 and ending in March 2017, which marked the first anniversary of the refugees' arrival. The results obtained show that both liberal and conservative-leaning media utilized frames in ways that correspond with their ideological stance. In most cases, the limelight rarely focused on Syrian refugees. Instead, they were used as props to push the news source's ideological convictions and to condemn and shame the opposition. Therefore, it is understood, that the framing and portrayal of refugees in this narrow manner through discursive strategies obscures the complexity of the plight of Syrian refugees and depicts them as one-dimensional characters that audiences would either fear or pity.
\end{abstract}

Keywords: Syrian refugees; critical discourse analysis; framing; Canadian online news media

\section{INTRODUCTION}

Like many nations in the Middle East, the Arab Spring did not yield the results Syrians had hoped for; instead, soon after protesters began demanding reform, the Syrian government retaliated with brutal force. Though initially, Syrians remained adamant in maintaining peaceful protest, civil war soon ensued. In the years that followed, millions of Syrians became internally displaced or sought refuge in neighboring countries. However, with refugee camps overcrowded, lack of medical assistance, and necessities, hundreds of thousands opted to leave these dilapidated camps and take the life-threatening voyage to Europe where the odds of living normal lives are higher. Reports from the United Nations estimate 6.1 million internally displaced Syrians and 5.6 million Syrian refugees worldwide, prompting the UN rights chief to call the Syrian issue "the worst man-made disaster since World War II" (UN News, 2017).

With any mass resettlement, news media outlets around the world focused not only on the resettlement of refugees but on how governments responded in aiding these refugees. Though Canada has a long and well-documented history of refugee resettlement (Hagan, 2001;

${ }^{a}$ Main \& corresponding author 
Powell, 2005; Beaudoin, Danch, \& Rehaag, 2015; Muhammedi, 2015), Liberal and Conservative politicians remained divided on how to respond to the situation appropriately. In turn, this made the Syrian refugee crisis a hot button issue in the debates leading up to the 2015 federal elections. After winning the general elections, the new Liberal government began executing its plan to resettle 25,000 Syrian refugees, which was not supported by the Conservatives who pledged to resettle 10,000 Syrian refugees from religious minorities.

At different points on the ideological spectrum, news media outlets disseminated news stories, either supporting or criticizing the resettlement operation. The difference in the representation of political and social actors involved in the resettlement initiative will help better understand how the public views and, in turn, reacts to the newly settled Syrian refugees.

This paper aims to answer the following questions:

1. What frames are employed in the representation of social and political actors involved in the refugee resettlement initiative in Liberal and Conservative-leaning news media?

2. How does the utilization of these frames differ in Liberal and Conservative-leaning news sites?

\section{LITERATURE REVIEW}

As the number of refugees and asylum seekers reached an all-time high in recent years, one is able to find an abundance of research on the topic of asylum seekers and the media. Most research centred on media in Europe, Australia, and the United Kingdom as they have witnessed a large influx of refugees in recent decades (Parker, 2015; Hanson-Easey, Augoustinos \& Moloney, 2014; Khosravinik, 2009, 2010; Lynn \& Lea, 2003; El-Refaie, 2001). Studies relevant to this research are discussed below.

El-Refaie (2001), Khosravinik (2009 \& 2010) and Parker (2015) examined the use of metaphors in the representation of asylum seekers in Austrian, Australian and British newspapers. Results showed that the dominant metaphors were used to portray refugees as "water", "criminals", "an invading army" and "the unwanted invader". The repetitive use of these metaphors indicated that they have become "...the natural way of describing the situation" (El-Refaie, 2001: 532). Hanson-Easey et al. (2014) used a discursive psychological approach to examine the representation of Sudanese refugees in naturally-occurring conversations on Australian talkback radio. Their findings correspond with El-Refaie (2001) in the sense that they were generally assigned violent- tribal attributes. The results of this research are further supported by Lynn and Lea (2003) who argued that the current representation of refugees in British media has led to the creation of a "new apartheid" for asylum seekers.

Venir (2015) and Yaylaci and Karakus (2015) contrasted the representation of Syrian asylum seekers in British and Turkish newspapers respectively. Their findings showed that newspapers employed different strategies in their representations due to their political standpoints. The representation of the refugees ranged from "victims" of the Assad regime to "guests" to "burdens and threats" (Yaylaci \& Karakus, 2015: 247), Venir (2015), concluded that the UK's involvement in the aid of Syrians has greatly affected the representation of Syrian refugees in British media and, in turn, led to an outpouring of public support.

The media has the power to create a sense of belonging that could aid immigrants in assimilating to their new environment. However, its negative representation of immigrants has had adverse effects on the immigrant population. Leudar, Hayes, Nekvapil and Baker (2008) conducted several interviews with locals and immigrants in the UK to examine local hostility towards immigrants, they concluded that news media plays an imperative role not only in 
constructing the image of the immigrant as a "social parasite" but also internalizing this image in the perceptions of both immigrants and local inhabitants who in turn begin to view them as such. Not surprisingly, after being depicted negatively by the media and viewed as such by the locals, immigrants experience psychological problems attributed to their situation.

In another study highlighting the role of the media in creating negative perceptions towards immigrants, Pearce and Stockdale (2008) interviewed laypeople and experts working in support of immigrants and compared their views about asylum seekers. Findings showed that the views of the public were highly affected by the media's depiction of refugees; the majority held negative views towards immigrants and refugees. However, they were easily persuaded to change their perception of how they viewed immigrants as "their views tended to become more positive throughout the course of interviews as they had the opportunity to consider the issue in more detail" (p. 154). Findings suggest that since most of the public relies on the media for its news, polls may exaggerate public negativity towards asylum seekers.

The aforementioned research shows that media has the power to create an image of the refugee (be it the unfortunate victim in need of rescuing or the violent invader) and present it to the public who will most likely consume and internalize this information.

\section{REFUGEES IN CANADIAN NEWS MEDIA}

The millions of immigrants and refugees moving into the country for many reasons have made Canada one of the world's most multicultural and global countries. According to Griffith (2015), over 20 percent of Canada's population is foreign-born with 250 different ethnic origins and these numbers are expected to increase. This increasing diversity in populations brings many colors to the country and yet also some challenges; the reception of newcomers has not always been embraced.

Although Canada has set a multicultural policy in 1985 whereby minorities are free to practice their religions and keep their identities without the fear of persecution (The Government of Canada, 2016a), this has resulted in the emergence of complex forms of racism. According to Mahtani (2001), Canadian media often under-represent ethnic and religious minorities and systematically depict these groups in a stereotypical manner where they are rarely represented as "people who have something important to say" (Mahtani, 2001: 6).

Canadian news media is not very different from its European counterparts, where refugee claimants are often represented as 'dangerous' and 'deceitful.' Studies focusing on the depiction of Mexican, Chinese and Tamil refugees in Canadian news concluded that the said refugees are -in most cases- depicted as a threat to national security, manipulators of a fragile and failing immigration system and 'Othered' (Hier \& Greenberg, 2002; Bradimore \& Bauder, 2011; Gilbert, 2013; Medianu, Sutter, \& Esses, 2015).

Additionally, Medianu, Sutter, and Esses (2015) emphasize the detrimental effects of this biased and often inaccurate representation have on minorities and future immigration laws: "By repeatedly referring to refugees as bogus, criminals and terrorists, the media can have a lasting effect on how members of the public perceive refugees. The media can also potentially affect how refugees are treated in society and how people respond to current and future immigration legislation concerning refugees" (p.10). This is reiterated by Gilbert (2013), who suggested that -within the Canadian context-, the alignment of media discourse and policy rationalization eventually led to the implementation of additional restrictions on refugee claimants.

On a related note, Reitmanova, Gustafson, and Ahmed (2015) had examined the framing of health and social issues of immigrants in ten Canadian dailies. They assert that through framing immigrants as disease breeders and irresponsible health fraudsters, the 
Canadian press has racialized immigrant health issues and moved in the direction of exclusion and marginalization.

Though Esses, Medianu, and Lawson (2013) suggest that the attitudes of the Canadian public towards minorities are more favorable than in many other Western nations, this should not divert from the fact that focusing on the 'negative' traits of immigrants and refugees will eventually plant seeds of resentment and fear in the hearts of Canadians. Though the arrival of Syrian refugees cannot be compared to that of the Chinese and Tamil refugees in 1999 and 2009, recent studies on the representation of Syrian refugees in Canadian media, social media, and parliamentary discourse have yielded some discouraging conclusions.

Tyyska et al. (2017) and Wallace (2018) had looked at the Canadian coverage of the Syrian refugee crises. Overall, three themes emerged in the Canadian media's coverage of the Syrian refugee crisis:

\begin{abstract}
Canadian values, specifically humanitarian and generosity representation of Syrian refugees as vulnerable and lacking agency gendered representation of male refugees as security threats while media make soothing noises about the openness and generosity of Canadians, they also continue to depict refugees along an inaccurate and misleading continuum between being needy and lacking agency, and as a possible threat [thus perpetuating] an uncritical view that endorses neo-colonial, orientalist, neo-liberal, anti-Islamic and patriarchal perspectives to both the refugees and the Canadian government and public.

(Tyyska et al. 2017, p. 14)
\end{abstract}

Johnston (2016) had focused on reporting on Syrian refugees before, during and after the 2015 Canadian federal elections. His research concluded that though initially Syrian refugees were framed in a negative light, a more positive representation dominated the media after the death of Alan Kurdi. Though research on refugee, immigrant, and minority representation in Canadian media is abundant, examining the relationship between the news sources' political affiliation and the coverage of the Syrian refugee resettlement initiative will yield significant insight on how the political climate, discourse, and public opinion are interconnected.

\title{
FRAMING THEORY
}

Framing is a vital part of the media message audiences take in. According to Lakoff (2004), "frame are mental structures that shape the way we see the world. As a result, they shape the goals we seek, the plans we make, the way we act, and what counts as a good or bad outcome. In politics, our frames shape our social policies" (p. xv).

Frames are produced by mass media and adopted by individuals and societies. These frames are "the central organizing idea for news content that supplies a context and suggest what the issue is through the use of selection, emphasis, exclusion, and elaboration" (Tankard, 2001: 11). Therefore, every news story disseminates a particular frame, and being able to identify and analyze the nature of said frames is an integral part of interpreting the messages disseminated by news media.

Entman (1993, p. 52) argues that "to frame is to select some aspects of a perceived reality and make them more salient in a communicating text, in such a way as to promote a particular problem definition, causal interpretation, moral evaluation, and/or treatment recommendation for the item described."

The framing theory has its roots in sociology in Goffman (1974) and was later adopted into linguistics in the work of Fillmore (1975). Though scholars of the human sciences often utilize framing theory, it is still relatively unstructured, Entman (1993) maintains that work on framing theory "remain fractured, with pieces here and there and no comprehensive statement to guide research" (p.51). He suggests that "while nearly everybody in the social sciences talks 
about framing, there is no clear understanding of what frames are and how they influence public opinion" (p. 51).

Frames as variables remain rather abstract, which complicate their objective measurement. Therefore, framing theory does not prescribe to a specific methodology, instead, bringing rise to several approaches (Matthes \& Kohring, 2008). Two framing approaches are relevant to this study. To begin with, the Hermeneutic approach, which is rooted in the qualitative paradigm, focuses on small samples that reflect the discourse of a certain issue. "Typically, [within the Hermeneutic approach], frames are described in-depth and no quantification is provided" (p.259).

For instance, Coleman and Dysart (2005) adopted the Hermeneutic approach when examining the framing of the Kennewick man. The news coverage was examined using -what they refer to as- a "close reading of all news articles that met the search parameters in the study'. By examining key words, phrases, and themes, they highlighted frames of conflict, war, religion versus science, etc.

Secondly, the Linguistic approach whereby frames are identified by analyzing the selection, placement, and structure of specific words and sentences in a text and the unit of analysis is the paragraph, not the article. The linguistic approach is similar to the hermeneutic approach. However, the linguistic approach determines linguistic elements that signify a frame (Matthes \& Kohring, 2008).

Adopting the linguistic approach, Esser and D'Angelo (2003) developed a rather detailed four-step method to extracting frames. In short, they began with purposively selecting the coverage of specific events. Next, they analyzed topics and linguistic or visual items on which journalists impose framing devices to frame a topic in a particular way. The third step included the analysis of the framing devices through syntax and visual and verbal prepositions which will finally lead to the identification of thematic wholes (i.e. frames). Due to its focus on smaller text segments, this method might work best when examining small text samples.

Several CDA scholars have incorporated framing in the study of argumentation; the most prominent being Fairclough and Mădroane (2014) who suggest "to frame an issue is to offer the audience a salient and thus potentially overriding premise in a deliberative process that can ground decision and action." (p.7). Fairclough and Mădroane (2014: 6) highlight the compatibility between framing and argumentation theory:

\footnotetext{
If the framing process aims to define and diagnose problems and suggest solutions, then it is involved in the form of practical, deliberative reasoning, oriented towards decision (and possibly) action, attempting to direct the audience towards a particular decision, a particular line of action. In framing an issue in a particular way, a communication source (media or political elites) supplies those particular premises that may lead the audience towards a particular conclusion.
}

Studying the representation of ethnic minorities or refugees through media framing becomes imperative in comprehending several social phenomena. First, it allows the researcher to recognize how these frames influence public opinion. Secondly, it will suggest how said frames promote various interpretations of how these groups should be treated or dealt with in the physical world. Finally, the study of frames will also give researchers a glimpse of how the construction and dissemination of these frames play a role in how ethnic minorities and refugees view themselves.

\section{METHODOLOGY}

Following the Discourse Historical Approach, this study investigates the construction of frames by utilizing two of the five discursive strategies proposed by Reisigl and Wodak (2009) (i.e., 
nomination and predication). These discursive strategies are said to be utilized by the elite to achieve specific social, political, psychological, or linguistic aims.

These discursive strategies have been utilized in a plethora of research (Salahshour, 2017; Samaie \& Malmir, 2017; Lawton, 2013; KhosraviNik, 2009 \& 2010). Depending on the research questions, the specificities of the social contexts and the qualities of the genre of data, some of these strategies may prove to be more significant than others (KhosraviNik, 2014). Therefore, considering the goals, scope and research questions, two of the five strategies are examined, namely: (1) Referential/nomination strategies (i.e., actor descriptions) and (2) Predication Strategies (i.e., action attributions).

Both strategies consider the linguistic construction of social actors, objects, events, processes, and qualification in terms of what actions, qualities, attributions, etc. are associated with the actors of 'self' and 'other.' (Salahshour, 2017). These strategies are realized through metaphors, metonymies, verbs and nouns.

Nomination and Predication strategies are realized through a number of rhetorical devices, specifically: (a) Naming and Lexical Choices- In analyzing articles for naming and lexical choices, the ways of referring to the participants of events were examined. According to Fowler \& Kress (1979: 200), "the different possibilities [of naming] signify different assessments by the speaker/writer of his or her relationship with the referred to or spoken to, and of the formality or intimacy of the situation". They point out that there are various forms of addressing people.

For example, public figures tend to be called by title plus last name. Additionally, Fairclough (2001: 97) argues that "a text's choice of wordings depends on, and helps create, social relationships between participants", thus lexical choices are ideologically significant. Choosing different words for referring to the same thing by different speakers reveals "different ideological affiliations" on the part of the speakers. For example, "refugee" versus "economic migrant". In the context of this research, the naming and lexical choices depicting Syrian refugees, members of the Liberal and Conservative parties and the Canadian public are examined in the selected news sources to recognize the manifestation of the news sources' ideological leanings.

For example, some of the lexical choices used to refer to the refugee resettlement program by the National Post and the Toronto Sun were 'problematic', 'hasty' and 'unrealistic', whereas the Toronto Star referred to the same program as 'success', 'remarkable successful humanitarian operation' and 'an example to emulate'. The lexical choices indicate the ideological affiliations of each source as the first two hold the same beliefs as the Conservative party and the latter is an avid supporter of the Liberal party.

(b) Metaphor - a defining feature of predication- is defined by Goatly (2007) as "thinking of one thing (A) as if it were another thing (B), and linguistically this will result in an item of vocabulary or larger stretch of text being applied in an unusual or new way" (p.11). The study of metaphor is prevalent in refugee and immigrant studies. Metaphors are used to depict unfamiliar people/events by referring to things readers are more familiar with. Research on the representation of minorities shows that water metaphors are commonly utilized by European and Western news media to refer to refugees.

(c) Deixis refers to expressions referring to social actors, time and place, such as "us" and "them". These expressions are used to implement nomination, where the utterer can appear to distance himself from an event or a group. The use of deictics will only be understood with the availability of some context. Reisigl (2007) highlights three deictic expressions that are often used in discriminatory discourse; personal deixis: "distancing and debasing 'they' and "those", local deixis: "such as 'down there' or 'out there"" and social deixis: indicating social position "X", "Mr. X", "Professor X" (p. 379). The aforementioned naming and lexical choices, metaphor and deictics are devices manifested through nomination and predication strategies to 
construct group membership and to construct boundaries between in-groups and out-groups (Reisigl \& Wodak, 2009).

The study aimed to examine three National Canadian online news sites: the Toronto Star, the Toronto Sun, and the National Post. These sites were selected due to their broad readership and popularity. According to News Media Canada (2015), the average daily reads of the Toronto Star is 318,763, the National Post is 186,108 and the Toronto Sun is 121,304 , placing all three sources in the top ten news sources with the highest readership. These news sites are also selected for their political orientation and ideological stances, i.e., the Toronto Star is liberal-leaning and the Toronto Sun and National Post are conservative-leaning.

Using each site's search engine, all articles related to the Syrian refugee resettlement initiative within 16 months were extracted, totalling up to 375 articles. Next, purposive sampling was used to downsize the sample. According to Ritchie, Lewis, and Elam (2003), the data are selected because they contain features or characteristics significant to the topic, thus enabling a detailed understanding of the central themes in the study. Amer (2017) adds that the aim of purposive sampling is "to be reflective (if not strictly representative) of the population" (p. 4).

The downsized sample consisted of thirty-one articles (Appendix A), representing the texts of the three selected news sites. The selected articles were reviewed and coded for reoccurring patterns relating to the depiction of the social and political actors (i.e., Syrian refugees, the Liberal government, the Conservative party, Canadians, and Canada) involved in the Syrian refugee resettlement initiative. Subsequently, as illustrated in table 1, six frames were identified.

TABLE 1. Identified Frames and Description

\begin{tabular}{|c|c|}
\hline Frame & Characteristics \\
\hline & - Uses nomination and predication strategies to depict the suffering of refugees. \\
\hline \multirow[t]{2}{*}{ Victimization } & - Reference to the plight of women and children. \\
\hline & $\begin{array}{l}\text { - Reference to the torturer, poor living conditions, and lack of basic amenities. } \\
\text { - Focus on the impact of refugees on the economy, the infrastructure of the country. }\end{array}$ \\
\hline Burden & $\begin{array}{l}\text { - Offers solutions to the refugees' crisis that do not entail resettling refugees. } \\
\text { - Focuses on the threats that come with resettling refugees. }\end{array}$ \\
\hline Threat & $\begin{array}{l}\text { - Covers a wide variety of threats (i.e. terrorism, threats to the economy, culture and } \\
\text { values) }\end{array}$ \\
\hline & $\begin{array}{l}\text { - Uses nomination and predication strategies to depict the ruling party as a godlike } \\
\text { entity. }\end{array}$ \\
\hline \multirow[t]{2}{*}{$\begin{array}{l}\text { Government } \\
\text { as the } \\
\text { Saviour }\end{array}$} & $\begin{array}{l}\text { - Focuses on the successes of the government and the shortcomings of the opposition. } \\
\text { - Highlights the gratitude of the refugees and the satisfaction of the public with the } \\
\text { government's actions. }\end{array}$ \\
\hline & - Focuses on the government's perceived failures. \\
\hline Irresponsible & - Highlights the unprofessionalism, deception and at times, tomfoolery of government \\
\hline \multirow[t]{3}{*}{ Government } & officials. \\
\hline & - Points out the dissatisfaction of the refugees and the public. \\
\hline & - Reiterates the country's humanitarian successes. \\
\hline The Nation & - Focuses on the values of the nation and its people. \\
\hline as a Utopia & $\begin{array}{l}\text { - Contrasts the great efforts of the nation with the lack of enthusiasm in neighbouring } \\
\text { nations. }\end{array}$ \\
\hline
\end{tabular}

\section{FINDINGS AND DISCUSSION}

The analysis of referential and predication strategies utilized in the texts will be presented alongside selected examples and longer extracts, which will be discussed in detail for illustrative purposes. 
Several frames were constructed by opposing media outlets. Nevertheless, all three sources shared the dissemination of certain frames, though at varying frequencies and intensity. By examining the representation of all aforementioned actors, six frames become prominent in the process of analysis. These frames are ordered based on their prominence within the analyzed articles: (1) the victimization frame, (2) the burden frame, (3) the threat frame, (4) the government as the savior frame (5) the irresponsible government frame and (6) the "nation as a utopia' frame.

\section{THE VICTIMIZATION FRAME}

The most prominent frame utilized in both Liberal and Conservative-leaning media is the victimization frame. It addresses issues relating to personal and emotional aspects of the crisis; in most cases, focus on the pain and hardships individuals go through is central to this frame. In the context of the Syrian refugee issue, the victimization frame is used to shed light on the humanitarian crisis, the need to help said refugees, and the efforts of the Canadian government and public in this humanitarian crisis. Many instances of this frame can be found in the humaninterest stories where news sources focus on a single refugee, a family, or a Canadian citizen's efforts in helping Syrian refugees.

The victimization frame is used in reference to Alan Kurdi's ${ }^{b}$ death which was brought up through his aunt's accounts not only at the beginning of the refugee resettlement effort but during and even after the completion of the project. By keeping his story alive in the collective memory of the public, the media motivates Canadians to do more, reminds them of the consequences of not taking action, and at times criticizes the government for not doing enough.

(1) "The photo of the Syrian boy's body, face down on a Turkish beach, graphically illustrated the magnitude of the migrants' suffering. Alan's brother, Galib, and mother, Rehan, were also among the five victims who drowned when their boat went down in the ill-fated journey from Bodrum to the Greek island of Kos last year". (T.SR 4, Mar, 16-1)

Excerpt (1) conveys a vivid picture of the gravity of Syrian suffering. It describes the position in which Alan was found and photographed, thus invoking the image in the collective memory of its readers. Within the victimization frame, both Liberal and Conservative-leaning media used strategies to individualize refugees. In many cases, refugees' first and last names are reported when narrating their experiences in human-interest stories (e.g., Kalar Tavit and Koko Kouren can't believe they're actually here). Additional information like giving actors possessions (big room) or depicting them as doing everyday activities (going to school, playing with friends, coloring) humanizes refugees and makes them relatable.

(2) "In his house in Damascus, 10-year-old Abdelkader had a big bedroom filled with sunshine that he shared with his whole family. So it's not so difficult, he says, to share a room with them now in a downtown Ottawa hotel." (T.SR 12, Mar, 16-1)

(3) "Now coming on five years old, Sham is going into kindergarten. She has loved her time in preschool so far at W.P. Bate School... She wonders why school isn't on the weekends, too. She loves to draw, even though holding a pencil crayon is painful. "It's a new world for her," Akraa said." (NP 27, Aug, 16-1)

\footnotetext{
${ }^{b}$ Alan Kurdi, also referred to as Ayan al-Kurdi, a three-year-old Syrian boy whose drowned body washed-up on September 2015 on a Turkish beach after trying to cross the Mediterranean sea with his family.
} 
The Liberal media's depiction of Syrian refugees as 'victims' revolved around their suffering in Syrian and refugee camps and as victims of smugglers.

(4) "They suffered so much in Syria - the bombing in Syria," said Alamour. "And in Jo rdan, there were no jobs. They had to go and get food from

organizations, or they worked and were scared they'd get arrested. Even here a sur vival job is better than anything in Jordan." (T.SR 19, Dec, 15-2).

(5) "The Kurdi family was among hundreds of thousands who risked the journey to Greece in the hope of then heading to wealthier nations in northern and western Europe. After the deaths of his family, Abdullah Kurdi has returned to Syria. The International Organization for Migration says at least 418 migrants have died this year alone while trying to cross into Greece or Italy. Turkish officials say authorities in 2015 detained more than 4,400 smugglers who organized the often -dangerous crossings in frail boats". (T.SR 4, Mar, 16-1)

The excerpts above are an example of the use of referential strategies in the depiction of refugees. Though the Star is sympathetic to the suffering of the Kurdi family as it has become a pivotal incident in Canada's history and thus policy-making, other refugees who suffered the same fate are reduced to numbers and referred to as 'migrants' looking to settle in 'wealthier nations' rather than refugees seeking safety. This not only illustrates the paper's doublestandard in depicting refugees but also serves to justify policies that allegedly aim to prevent this abuse, others 'illegal' refugees, and reaffirms the humanitarian credentials of the in-group.

Additionally, the Toronto Sun and National Post depicted government-sponsored refugees as 'victims' or poorly treated, the news sources focused on instances where Syrian refugees were not given the necessary attention or aid to assimilate and were left to fend for themselves. A number of instances depicting them as victims of scammers and hate crimes were found in both Conservative-leaning sources. Depicting Syrian refugees as victims even after coming to Canada is a deliberate stab at the Liberal's efforts towards the refugees. Contrary to these claims, Agrawal (2018) maintains that privately sponsored refugees faced resettlement challenges similar to their counterparts in the government-sponsored program. However, the misconstrued belief that government-sponsored refugees face more adversity dominates public opinion.

Though the victimization frame calls for Syrian refugees' aid, it nevertheless depicts them as somewhat passive actors waiting for rescue and, in turn, depicts Canada, the Canadian government, and people as the 'rescuers.' It is essential to acknowledge that victimization should not necessarily mean passivity. In most cases, as is the case with Syrian refugees, individuals do not immediately leave their homeland; they live in extreme conditions, become internally displaced, and finally, decide to leave their homeland. The media often ignore this 'agency' and thus, it becomes unlikely to find empowering representations of refugees. Refugee success stories are rarely covered, and their representations as influential or valuable members of the public are almost non-existent.

\section{THE REFUGEE AS 'A BURDEN'}

This frame mainly manifests itself in metaphors. The use of metaphor in representing refugees, immigrants, and minorities in different media sources is highlighted in several studies (Torma, 2017; Parker, 2015 \& KhosraviNik, 2009). Reoccurring metaphors found in both Conservative and Liberal sources were 'refugees as water' and 'the country as a container' metaphor. Refugees are described as waves that keep coming or an unstoppable river flowing into the country, implying that like real waves in the water, the refugee influx is unrelenting and regular; 
(6) "It's a lost cause, though, with more kids soon taking their place in the hotel that's been transformed into a temporary refuge for Syrian refugees who are pouring into town." (NP 22, Jan, 16-1)

(7) "[vowing to hire 100 refugees is] a big promise but small compared to the flood of refugee job-seekers. Canada expects to welcome 44,000 Syrian refugees by year-end, four times the total refugees in 2014." (NP 20, Nov, 16-1)

In the two excerpts above, the water metaphor conveys the overwhelming situation and the great burden placed on the country's shoulders to handle the 'flood' of refugees 'pouring' into town and looking for housing and work. Using this aggregation strategy to point out the number of refugees in (7) and referring to the country's efforts as 'a lost cause' in (6) make refugees appear as an indistinguishable mass. This not only dehumanizes and suppresses individuality but also suggests unfeasibility in controlling the 'situation,' which conveys the notion of threat and urgency of action and makes the lexical choice of 'welcome' in (7) somewhat ironic.

Another entailment of the 'refugees as water' metaphor, which corresponds with Torma (2017), is that the refugees "need to be contained in much the same way that we try to contain water by dams or diversions" (p.17). This gives rise to more general expressions such as "control the flow of refugees" or "to stem flow of refugees":

(8) "Temporary processing centres have been set up to handle the waves of newcomers at Toronto's Pearson airport and Montreal's Pierre Elliott Trudeau airport." (T.SR 10, Dec, 15-1)

(9) "Several Ottawa agencies are calling for a pause in the flow of Syrian refugees coming into the city, saying that they need to get better organized to handle the numbers." (NP 22, Jan, 16-1)

In the examples above, regardless of the provisions taken to deal with these 'waves' and 'dramatic inflow,' the magnitude of the wave is too much to handle leading agencies to 'pause the flow.' The water metaphor extends to depicting the confusion regarding the number of refugees allowed into the country by asking whether refugees will be coming in a 'steady flow or a trickle.'

The water metaphor is extensively utilized because most people have extensive, shared knowledge about it. El-Refaie (2001) suggests, "the fact that the refugees came across the sea seems to have created a strong sense of a 'natural' thematic link between the people and the water" (p.359). She also points out that the water metaphor is used when depicting refugees coming from the Middle East or North Africa. Therefore, although Syrian refugees did not come to Canada by sea, the same metaphor is extended to Canada's Syrian refugees. This is further intensified by the descriptions of a metaphorical journey across the ocean;

(10) "Rakan and his family are among the many Syrian refugees headed for Canada's shores as part of the federal government's response to help with the crisis." (T.SN 6, Dec, 15- 1)

(11) "This country has shown much compassion and goodwill to those arriving on our shores, but that compassion will inevitably get a tougher test." (T.SR 13, Jan, 16-1)

Though the mention of Canada's 'shores' in both Liberal and Conservative sources could be figurative, nevertheless, it is possible that in a way, it is grouping 'legal' Syrian refugees with 'illegals' in the past who have entered by sea. 
The burden frame is utilized by depicting Syrian refugees as a liability to the host country's infrastructure and taxpayers. This is supported by the common misconception that refugees cause an economic burden on the host country and that skilled workers make a more significant contribution. Though this is correct in the short-term, research has found that refugees eventually catch-up with their peers and often become financially independent of government support (Stevenson, 2005; Boese, 2009, Wilkinson \& Garcea, 2017).

Though this rationalization might be true in cases where refugees enter a country illegally; since the host country might not be prepared to assist them. Within the Canadian context, officials agreed beforehand on the number and educational background of the Syrian refugees they would be admitting, and thus equipped themselves and organized their efforts accordingly. Schwöbel-Patel and Ozkaramanli (2017) raise an interesting point about the burden of refugees. They argue that refugees will be depicted as a burden, either way, they refer to the dilemma of what they call 'Schrödinger's immigrant,' who is simultaneously stealing locals' jobs and too lazy to work.

\section{THE THREAT FRAME}

A dominant frame found in articles published in Conservative news sources reinforces the depiction of Syrian refugees as a threat to Canadian values and security. Though refugees' impact on the country's economy was discussed, refugees were mainly depicted as a burden rather than a threat when it came to their economic impact. Though only Conservative sources accused Syrian refugees of posing a threat on Canada, the Toronto Star, in an effort to provide a counter-argument to the claims put forth by its Conservative counterparts, published the following excerpt:

(12) "We have not been tested like Germany or Greece, both brimming with migrants of indeterminate origin. By virtue of our splendid geographic isolation, we are largely spared the waves of boat people who risk drowning at sea, or the stampedes at border crossings that wreak havoc with sovereignty". (T.SR 12, Dec, 15-3)

The Toronto Star intended to contrast the scene in Canada to that of Germany and Greece. Nevertheless, the lexical choices, dehumanizing metaphor (brimming, waves, stampede), hyperbolic phrases (wreak havoc), and deictic positioning, 'we' are protected from 'them.' All this shows that, if the tables were turned and Canada did not have control over its refugee admission, Syrian refugees would have been depicted in the same distant and inhumane manner.

When discussing the 'negative' effects of Syrian refugees on Canadian culture, the Toronto Star references the importance of educating refugees about Canadian cultural values in several excerpts.

(13) "The integration phase is ultimately the most important phase, to make sure that these Syrian refugees become well integrated into Canadian culture, that they understand our cultural values and practices and that will be done through a number of mechanisms," said Health Minister Jane Philpott.” (T.SR 13, Jan, 16-3)

Through emphasizing the importance of adopting Canadian values, the difference between us and them is highlighted. The fact that 'a number of mechanisms' are needed to reeducate Syrian refugees and make them 'understand our cultural values' speaks volumes about the vast cultural chasm separating Syrian refugees from their Canadian hosts. 
On the other hand, Conservative media was not as accommodating and instead of focusing on integration, they began a weak attempt to generalize and compare Syrian refugees to a criminal of Afghani descent;

(14) "over my assertion we need to be careful about who we let in as immigrants and refugees. [the panelists] both insisted there is no problem with arrivals from other countries, nor will there be. When I asked about the Shafia family, there was no response, other than to continue to assert that immigrants and refugees pose no danger to our safety or "Canadian values," a term which, sadly, too many people mock. But it is decidedly not a Canadian value to murder a daughter deemed to have shamed the family." (T. SN 1, Nov, 16- 1)

The author's outlandish and out of place reference to the Shafia family case where a father was charged for the 'honor killing' of his daughters and wife is irrelevant and in no way can be brought up as an argument against taking in Syrian refugees.

The Shafia family were of Afghani descent, thus culturally distant from Syrians; they also came to Canada as immigrants and not refugees while the Canadian government was under Conservative rule. Therefore, the Liberal government cannot be blamed for lax immigration procedures. Last but not least, the incident had taken place seven years prior in 2009. The only reason for referencing this gruesome murder is to tap into the collective memory of Canadians and create a link between horror and outrage that ensued in 2009 and the possibility of reliving it in 2016 (Department of Justice, 2016). The strategy of referring to terrorist attacks to remind the public of the risk they are taking by accepting refugees into their communities is pervasive. However, since Canada's experience with terrorist attacks is minimal, the reference to domestic violence and attacks in neighboring countries are mentioned to draw the public's attention on what might happen to them;

(15) "Many of the millions of newcomers to Europe continue to form their own parallel societies, often completely at odds with the values and norms of their host society. Angry and violent young men joined the incoming migrants and radical jihadists have been able to enter Europe amidst the chaos. Concern about this type of migration is not about race or ethnicity. It's scarcely about religion. Rather, people throughout the Western world are concerned about the consequences of mass migration without security checks and proper integration". (T.SN 6, Jul, 16-1)

Again, excerpt (15) begins with a vague quantifier 'millions' and relying on hyperbolic phrases like 'completely at odds with' and 'amidst the chaos' and derogatory lexical items placing male refugees under the umbrella of 'anger,' 'violence' and 'radical jihad.' Interestingly, after alluding to Middle Eastern culture and religion, the writer emphasizes the point that he is not targeting a certain group of people (i.e., Arabs/ Muslims) but only highlighting the issues that might arise from allowing refugees to enter the country without proper security checks.

The racial profiling and stereotyping of Arab men as violent and angry is consistently disseminated in Western media, merely having different values and traditions is seen to pose a threat on Western society. Though the writer tries to distance himself from sounding racist, one must ask, would these concerns be raised if the said refugees were of the Christian faith?

In another demonstration of the angry Middle Eastern man, cases of domestic abuse are brought to the reader's attention;

(16) "While domestic violence happens everywhere, in some parts of the world it may be considered permissible to abuse one's wife and children. Anger and violence may be 
a part of everyday life. But that behaviour isn't welcome, or allowed, in Canada". (T.SN 25, May 16-1)

(17) "We should have told every refugee coming into Canada that cowardly practices like domestic abuse are illegal and not tolerated here. Instead, the Trudeau government rushed to bring over Syrian families, including, clearly, some men prone to domestic violence, without asking if they could adapt to our society." (T.SN 25, May, 16-1)

The excerpts presuppose that violence is in the DNA of the Arab man who seems to indulge in domestic abuse as 'part of everyday life.' Since 'some' of these men find it acceptable to abuse their family and, in turn, create a threat to Canadian values and society, a natural reaction is to stop allowing male refugees into Canada.

Though domestic abuse is a serious crime and should be treated as such, the Toronto Sun gives the impression that domestic violence is a foreign construct for Canadians, which is very far from the truth. According to a report published by the Government of Canada (2016b), one-third of all reported crime is domestic abuse. The report states that domestic abuse is underreported to the point that less than one in five (19\%) who had been abused by their spouse reported the abuse to the police. Therefore, domestic violence is not unique to Middle Eastern society, nor is it non-existent in Canadian society.

It would be a more constructive reaction to promptly and effectively deal with these violent individuals instead of using them as a representation of the Arab man as this has been shown to have a detrimental effect on all parties involved and will hinder the process of assimilation that everyone is patiently waiting.

It is important to mention how the deixis is used to provide a vantage point of the speaker. Hart (2011) points out how a country can be seen as a 'container' and how we tend to construe the situation from the perspective of the "us" who are already in the container, rather than the "them" who have just entered it. This vantage point is manifested in the excerpts by using deictic phrasal verbs like 'come in,' 'let in' and 'arrive.'

Actors are predicated as having a different set of social values and are construed as moving toward the host country, leading to a clash of ideologies. Deictic expressions (e.g., personal pronouns and possessives) can be used to position actors in separate social categories to the speaker/author, at value-oriented coordinates not shared by the speaker (i.e., not sharing the same set of social values), and thus establish relations of distance and difference between in-groups and out-groups (Hart, 2011).

\section{THE GOVERNMENT AS THE 'SAVIOUR' VS. THE 'IRRESPONSIBLE' GOVERNMENT FRAME}

The phenomenon of framing the government or Liberal party as the savior is found exclusively in Liberal media. Regarding nomination and predication strategies utilized by the Toronto Star, the prime minister, and government officials are referred to by their titles, first and last names, additionally, several lexical items, metaphors, hyperboles, and predication strategies were found that depict them as not only 'national heroes' but in a way 'global heroes';

(18) "It feels like someone has turned on the lights, and Canada has become a beacon of hopefulness. Much of the credit goes to Justin Trudeau and his sunny ways, his generous nature, his confidence on the global stage, his penchant for mingling with people ... all kinds of people." (T.SR 14, Dec, 15-2)

(19) "By being on hand at Pearson airport, Justin Trudeau achieved a larger purpose than just putting a telegenic face on a Liberal policy. Pictures of Trudeau welcoming the first contingent of Syrian refugees in person were published worldwide. It had been 
a while since Canada had been presented as a positive model to the rest of the world. It had also been a long time since Canadians from across the political spectrum mobilized behind a cause" (T.SR 15, Dec, 15-1)

The use of figurative language in the extracts in the form of metaphors and hyperboles is noteworthy. In addition to the emphases on the positive personality traits of the prime minister, Trudeau's actions were exaggerated to a certain extent; he 'turned on the lights', made Canada 'a beacon of hope,' 'achieved a larger purpose,' 'became a positive role model to other leaders' and 'mobilized' an army of good-doers. All of this presupposes that with the Conservatives in power, Canada was a dark, hostile, and divided place. This, however, changed with the return of the Liberals.

Canada has had a long and mixed history of responding to refugee crises. Both Liberal and Conservative governments have resettled refugees. Under Liberal leadership, Canada resettled 60,000 Indochinese refugees in 1972 and 11,000 Bosnian refugees in the 1990's. Similarly, Conservatives admitted 37,000 Hungarian refugees in 1957 (Bangarth, 2019). Although more' generous' than the Conservatives, the Liberal party's response to the Syrian refugee crisis is not unique to the party. Therefore, Canada was neither in darkness, nor was it a hostile place before the Liberal took power after losing to Conservatives in three consecutive elections.

Similarly, immigration Minister John McCallum received similar praise in the following excerpt:

(20) "He has put his money where his mouth is, explaining that he and his family have made a donation to help a Syrian refugee family. His wife, Nancy Lim, is an immigrant herself, originally from Malaysia. She, too, shares the excitement McCallum feels about his new job and the plan to welcome refugees to Canada. "She's pretty excited about it," he said. "She gives me good advice about various issues along the way."" (T.SR 28, Jan, 16-2)

The use of the phrase 'put his money where his mouth is' depicts him as an individual who would contentedly put himself at 'financial risks' in the pursuit of what he believes in and as a way of showing his commitment to and confidence in the Liberal resettlement program, he had decided to sponsor a Syrian family. Though mentioning McCallum's 'good deed' is relatively repugnant, what is more, outrageous is mentioning that he is married to an immigrant.

Through this, the author commits three offenses, the first being, equating immigrants to refugees. An immigrant is someone who decides to relocate to another country to improve life prospects, whereas a refugee is forced out of their country. Secondly, the assumption that because he is married to an immigrant, this makes him more empathetic and compassionate towards refugees. Finally, mentioning that she gives him advice is somewhat odd since her only credentials in this field are being an immigrant. Which begs the question, how is her advice valuable or even relevant?

On the other side of the spectrum, Conservative media framed the Liberal government as the anti-hero:

(21) "Trudeau and his ministers rush headlong into the concrete pylon of reality on file after file - the discarded commitment to bring 25,000 Syrian refugees to Canada by the end of 2015 being only the most obvious example" (NP 7, Jan, 16-1)

In the excerpt above, the prime minister is referred to by 'formal nomination,' i.e., his last name 'Trudeau.' The nominal group 'his Ministers' is semantically connected through the 
cohesive relation of 'coreferentiality' where the name and the possessive pronoun his "have the same reference" to the nomination Trudeau. Therefore, the actions of 'Trudeau' and 'ministers' are one of the same. The actions of the Liberal party are juvenile and uncalculated. The extratextual knowledge facilitates coherence, as rushing into a concrete pylon is commonly known to cause a -probably serious- accident.

Additionally, though Liberals were criticized for their enthusiasm for bringing 25,000 refugees in a matter of months, they are also criticized for not going through with the plan after they decided to push the deadline. The National Post refers to their 'discarded commitment' and presupposes that it is not their first nor last unfulfilled promise. In other words, the excerpt depicts the Liberal party as inexperienced and unrealistic. This criticism of the Liberal party continues in the excerpt below:

(22) "Prime Minister Justin Trudeau is quick to accept praise for his Syrian refugee pledge. Immigration Minister John McCallum called it "mission accomplished." But when serious problems surface - lack of resources for newcomers, refugees relying on food banks, violence within the Syrian refugee community, and so on - the Trudeau government is missing in action". (T.SN 6, Jul, 16-1)

(23) "The orgy of congratulatory backslapping that has gripped the country for several months now is way over the top. A little perspective is urgently required". (NP 28, Dec, 15-2)

Noteworthy here is how the Liberal part is equated to the Bush administration in (24). The Toronto Sun refers to what is frequently remembered as Bush's "Mission Accomplished" speech, which was given weeks after the United States invaded Iraq. Of course, the situation in Iraq quickly deteriorated and expanded into a decade of bloodshed and wasted millions. Although the situation in Canada is nowhere near as severe as the one in Iraq, the Sun hints at the irony of the Liberals (Trudeau government) celebrating their success before actually 'assimilating' Syrian newcomers into Canadian society and failing to manage arising obstacles. This is also seen in (23), where the National Post uses explicit language to refer to the 'over celebration' of the Liberal party.

The Liberal's simplistic and approach in dealing with the spending on the refugee program is also highlighted in the following excerpts:

(24) "How much will it cost to waive the immigration loan program? Once again, McCallum and his officials told the committee they didn't know.

Instead, McCallum deflected the question by bragging about his budget. Despite all the problems on the ground, all the refugees still waiting for services, the government somehow managed to come in $\$ 136$ million under budget.

They can't tell us how much various aspects of their program will cost taxpayers, but they know the pie-in-the-sky figure they gave themselves a few months ago was too high even for them to spend." (T.SN 10, Jun, 16-1)

Again, the minister of immigration is referred to by 'formal nomination' (i.e., McCallum) and semantically connected to the nominal group 'his officials.' Thus in a way, they are all placed under the umbrella of accountability. Bongelli, Riccioni, and Zuczkowski (2013) reinforce this notion by arguing that politicians and media tend to describe their political party, their actions, ideas, programs, their "Self" in a positive way and the opposition party, the "Other" as negative, untruthful or incompetent.

This can also be seen in the use of the possessive determiner in 'bragging about his budget' when referring to the Liberal's budget. The use of the deictic expressions (his, their, 
them) distances the news source from the government and thus emphasizes the condemnation of their achievement.

Additionally, the contrast between the use of the modal verb 'can't tell' to convey inability and 'know' to reflect certainty conveys the irony of the situation. This is further emphasized by using the idiom 'pie in the sky' to refer to the Liberal's preliminary budget. In the two excerpts below, the Liberals are depicted as dishonest at best (quietly releasing inaccurate costs) and imbeciles at worst (celebrating before the task is complete):

(25) "In June 2016, the government quietly released "preliminary costs" for the program, and pegged the costs $\mathbf{3 5 0} \%$ higher than Trudeau's campaign pledge. That way, six months later when the updated financial figures became available - and Trudeau only went $285 \%$ over budget - the Liberals could pat themselves on the back and celebrate." (T.SN 25, Nov, 16-1)

(26) "Prime Minister Justin Trudeau has said that the "budget will balance itself" and that our economy grows "from the heart out." So it isn't exactly surprising to find out that one of Trudeau's campaign promises has gone massively over budget." (T.SN 25, Nov, 16-1)

Interestingly, the Toronto Sun did not offer exact numbers to illustrate government spending but opted for using percentages; these vague figures are more shocking for readers. Additionally, the prime minister is quoted out of context in two separate instances once in "budget will balance itself," the full quote being "the commitment needs to be a commitment to grow the economy and the budget will balance itself" (Trudeau, 2014) and "economy grows from the heart out" which was followed by an explanatory tweet "Great to talk to people in Regina about our plan to strengthen the heart of the Canadian economy: the middle class" (Trudeau, 2015). Taking these quotes out of context help create an image of an incompetent leader. Finally, utilizing the hyperbole in 'massively over budget' presents a natural result for electing unskilled leadership.

Historically speaking, there are two noteworthy periods in terms of the highest increase and highest decrease in the size of government spending; the first was from the late 80s to early 90 s and second was in the late 90 s to mid-2000s. In both periods, the Liberal government was in power. Therefore, one cannot presume that either Liberals or Conservatives spend less or more. Kelly-Gagnon \& Geloso (2013: 4) eloquently expressed the importance of correctly understanding the economic reality by going "beyond ideological clichés and the official statements of political actors and focus instead on facts and statistics."

An obvious distinction can be seen in the depiction of the Liberal government in Liberal and Conservative-leaning news sites within these frames. The Toronto Star created a sunny and humanitarian image of the Liberal party and its leadership, whereas the Toronto Sun and National post told stories of refugee neglect, overspending, and premature celebrations. In both cases, elements of exaggeration, where positive 'self' and negative 'other' representation are present within all three sources.

Although Conservative media does not adopt a populist tone, through the framing of the Liberal government as careless and incapable of properly executing the Syrian refugee program, it implicitly cultivates a feeling of instability through this frame. It provides a representation of a potentially catastrophic future that will become a reality because of the government's irresponsibility. 


\section{THE 'CANADIAN UTOPIA' FRAME}

Within this frame, both Liberal and Conservative sources mainly relied on direct and indirect quotes by refugees, the Canadian public and government officials to create a frame where Canada is presented as a tolerant beacon of acceptance and multiculturalism:

(27) "As contemporary events clearly demonstrate, Canada is a nation of immigrants. It's embedded in our cultural fabric and is part of what defines us. Some of us have been here for generations, others have just arrived, but most Canadians have an immigration story, be it a first-hand account or one passed down through the family." (NP 1, Feb, 16-1)

(28) "The more we engage and welcome new immigrants, the more they will understa nd what it means to be Canadian, and feel part of the Canadian family" (T.SN 11, Mar, 16-1)

(29) "This is Canada. The nation that received immigrants from all over the world to be one nation" (T.SR 13, Mar, 17-1)

Ideologically laden lexical items are strewn about in all three sources, for example; 'a nation of immigrants', 'a country of peace', 'determination', 'national pride', 'lift weary souls', 'Canadian family', 'one nation', 'the best country', 'lifelong bond', 'acceptance and appreciation', 'safe', 'respected', 'the strong community', 'newfound freedom', 'dignity', 'generous and accommodating', 'compassionate', 'tolerant', 'determined', 'inspired', 'the most diverse society', 'bright', 'hopeful'. These representations are a common example of national-glorification and self- congratulations as a discursive positive self-representation strategy.

In the excerpts above, authors convey a sense of inclusivity and presupposed unity. This is achieved by referring to the metaphorical 'cultural fabric' and including Syrian refugees in the 'us' group and connecting them to Canadians who share similar experiences. Additionally, referring to the country's acceptance of refugees in the Conservative sources as 'our great strength,' and 'our greatest contribution to the world' not only glorifies the 'us' as a humanitarian power of change but presupposes that accepting refugees is not new to Canada which somewhat diminishes the Liberal's efforts.

In the excerpt below, the Toronto Star also disseminates the narrative of unity by referring to politicians' efforts from across the ideological spectrum, thus depicting a more homogeneous society. Additionally, the efforts of 'we' Canadians are contrasted with other first world countries 'them' who are alluded to as racist. Having said that, the excerpt ends on a different note. The Toronto Star points out that Canada has become a better place with Liberal leadership; this is done through positive lexicalization; 'new enthusiasm bubbling up everywhere.' Use of indexical expressions or deictic markers such as 'we' and 'now' to create a shared sense of community while 'us' and 'then' is used to exclude and insult. This is represented as us vs. them, which is used to detach the Liberal's achievements from the Conservatives':

(30) "But it's not just Trudeau that has made Canada a sunnier place, a place where robust kind- heartedness trumps fear. There are scores of other politicians, activists, and people determined to help who have spoken out against racism and pitched in to show the world that Canada is not like the U.S, or Hungary, or many other European countries that are refusing to shelter refugees.

When not only the prime minister, but also the premier of Ontario, the mayor of Toronto and federal opposition politicians show up to welcome Syrian refugees, Canada looks like a vastly different place than it did two months ago. And the new enthusiasm is bubbling up everywhere." (T.SR 14, Dec, 15-2) 
Particularly noteworthy is that all three sources have sung the praises of Canada and its people; Canada, the land of love, opportunities, freedom, safety, diversity, openness, and tolerance. The discursive construction of a unified nation creates a sense of harmony and a shared feeling. The discursive strategy of consensus is used to raise the feeling of togetherness and agreement. This helps readers to find the content of any news story more relatable. In other words, if a news source praises or criticizes the government or the Syrian refugees, readers will be more inclined to believe what is being said because they have been exposed to the said news sources' loyalty to Canada and its people. Additionally, this bond with the audience is established further by reminding them of their history and their trials and triumphs as a nation;

(31) "Our history is full of such stories of diverse people helping each other through hard times" (NP 1, Dec, 15-1)

(32) "The government's plan is grounded in the shared conviction and in our history of compassion." (NP 8, Mar, 16-1)

Again, the emphasis on 'our' is visible in the two excerpts above where history, diversity, and a strong connection or inclination to do what is right. The use of personal deixis (i.e., personal pronouns and their variants; mine and ours) in quotes highlights the relationship of power and solidarity within the 'in-group.'

Furthermore, in order to create a tangible frame of the 'nation as a utopia,' quotes from refugees are utilized to substantiate this claim;

(33) 'Refugee family thanks sponsor 'angels' for perfect new home.

So many lending a hand to help house Syrian refugees" (T.SR 7, Feb, 16-1)

(34) "I want to explore everything around me. It will be a very good opportunity to build, to rebuild my life in this country. I'm grateful and thankful for that opportunity. I'm lucky also because I came with my family and they're safe." (NP 6, Dec, 15-1)

Quotes like the ones above were found in all three sources. Canadians are referred to as angels, best people, wonderful people, exceptional and altruistic, and Canada is painted as a haven through place adverbials and lexical items like 'peace,' 'safe,' and 'home.' These exclusively positive and at times, hyperbolic references play an important role in seeing that they come from the refugees. Though several studies highlight the fact that refugees are often depicted as ungrateful and dissatisfied with the treatment of the host nation (Atkins, 2017; Schwöbel-Patel \& Ozkaramanli, 2017), the gratitude conveyed in these quotes does not necessarily reflect in a positive light on Syrian refugees, instead it emphasizes Canada's uniqueness and superiority.

The genuine gratitude expressed by Syrian refugees is echoed in a number of studies (Scott \& Safdar, 2017; Oudshoorn, Benbow \& Meyer, 2019), however, the same studies point out gaps in community integration and the need for establishing intergroup connections. When readers are regularly exposed to stories on gratitude and appreciation, they might unconsciously feel superior and no longer actively attempt to integrate newcomers into their social circles.

\section{CONCLUSION}

This study focuses on the utilization of referential and predication strategies in framing social and political actors involved in the Syrian refugee program. The ideological stance of the examined news sources was unequivocal in its framing of the Canadian government, whereby the Liberal government was framed as the 'savior' in the Toronto Star and as 'irresponsible and incompetent' in the Toronto Sun and National Post. 
This distinction was also present in the depiction of Syrian refugees, who had been framed as victims by Toronto Star and as a burden and threat in the Conservative Toronto Sun and National Post. Although Conservative sources have also contributed to the victimization frame, in most cases, the Liberal party was often viewed as the perpetrator.

Sources at both ends of the ideological spectrum are unanimous on Canada's greatness and hospitality and its empathetic people. All sources primarily presented Canada as a utopian society with an altruistic history whose citizens place the refugees' needs above their own. Framing the nation and its people positively is imperative in establishing credibility and, in turn, positive audience reception.

Within the articles published in competing news sources, the limelight rarely focused on Syrian refugees. Instead, they were used as a prop to push the news source's ideological convictions and to condemn and shame the opposition. Therefore, it is understood, that framing and portrayal of refugees in this narrow manner through discursive strategies obscures the complexity of the plight of Syrian refugees and depicts them as one-dimensional characters that audiences would either fear or pity.

Although Canadian the media prides itself on its respect for multiculturalism and diversity, it is not very different from the media in other host countries. The findings of this study correspond with previously published research examining the depiction of refugees and minorities around the world (Parker, 2015; Hanson-Easey, Augoustinos \& Moloney, 2014; Khosravinik, 2009, 2010; Lynn \& Lea, 2003; El-Refaie, 2001). The fact of the matter is depictions of refugees will remain ideologically motivated.

The fact that religiously motivated hate crimes rose to $47 \%$ a year after the resettlement of Syrian refugees (Statistics Canada, 2018) speaks volumes about the impact of media representation on public perception. This is rather a shallow representation of Syrian refugees. Therefore, it is imperative for the government and media elite to practice what they preach as this ambivalent representation of Syrian refugees has broad and enduring ramifications on race relationships.

Taking the findings of this study into account, future research can involve focusing on parliamentary discourse. Examining the 'source material' disseminated by news media will offer great insight into how the 'political elite' view and address the ever so important refugee issue and the factors that interplay in framing refugees in political rhetoric. Additionally, researchers might also investigate how the newly settled Syrian refugees view themselves. Personal narratives can provide researchers with an understanding of the extent of damage a negative depiction has on their resettlement and assimilation.

\section{REFERENCES}

Agrawal, K. S. (2019). Canadian Refugee Sponsorship Programs: Experience of Syrian Refugees in Alberta, Canada. Journal of International Migration and Integration, 20, 941-962 (2019).

Amer, M. (2017). Critical discourse analysis of war reporting in the international press: the case of the Gaza war of 2008-2009. Palgrave Communications, 3(1), 1-11.

Atkins, P. (2017). 'And it began by naming them': a critical analysis of the discourse of refugees in the Mass Observation diaries 1939-40, compared to that of their counterparts in modern Britain. Unpublished Master Thesis. University of Sussex, United Kingdom.

Bangarth, S. (2019). Canada's Complicated History of Refugee Reception. In D. Ross (Ed.), Confronting Canadian Migration History. (pp. 9-16) Toronto: Pressbooks.

Beaudoin, J., Danch, J., \& Rehaag, S. (2015). No Refuge: Hungarian Romani Refugee Claimants in Canada. Osgoode Legal Studies, 11(3), 1-58. 
Boese, M. (2009). Exploring Economism in Migration Policy And Research, TASA Conference, 1 st - 4th December, Canberra.

Bongelli, R., Riccioni, I., Zuczkowski, A. (2013). Certain-Uncertain, True-False, Good-Evil in Italian Political Speeches. In: I. Poggi, F. D’Errico, L. Vincze, A. Vinciarelli (Eds.) Multimodal Communication in Political Speech. Shaping Minds and Social Action. Lecture Notes in Computer Science, vol. 7688. Springer, Berlin, Heidelberg.

Bradimore, A., \& Bauder, H. (2011). Mystery Ships and Risky Boat People: Tamil Refugee Migration in the Newsprint Media. Canadian Journal of Communication, 36(4), 637661.

Coleman, C. L., \& Dysart, E. V. (2005). Framing of Kennewick man against the backdrop of a scientific and cultural controversy. Science Communication, 27, 3-26.

Department of Justice. (2016). Preliminary Examination of so-called "Honour Killings" in Canada. Retrieved 13, February 2018 from https://www.justice.gc.ca/eng/rp-pr/cj$\mathrm{jp} / \mathrm{fv}-\mathrm{vf} / \mathrm{hk}-\mathrm{ch} / \mathrm{p} 2 . \mathrm{html}$

El-Refaie, E. (2001). Metaphors We Discriminate By: Naturalized Themes in Austrian Newspaper Articles About Asylum Seekers. Journal of Sociolinguistics, 5(3), 352-371.

Entman, R. M. (1993). Framing toward clarification of a fractured paradigm. Journal of Communication. 4(43), 51-58.

Esses, V. M., Medianu, S., \& Lawson, A. S. (2013). Uncertainty, Threat, and the Role of the Media in Promoting the Dehumanization of Immigrants and Refugees. Journal of Social Issues, 69(3), 518-536.

Esser, F., \& D'Angelo, P. (2003). Framing the press and the publicity process: A content analysis of meta-coverage in campaign 2000 network news. American Behavioral Scientist, 46, 617-641.

Fairclough, N. (2001). Language and Power. London: Routledge.

Fairclough, I., \& Mădroane, I. D. (2014). An argumentative perspective on framing. Policy conflict, deliberation and framing in the Roşia Montană case. Paper presented at the 8th Conference of the International Society for the Study of Argumentation. 1-3 July.

Fillmore, C. J. (1975). An alternative to checklist theories of meaning. In C. Cogen (Ed.), Proceedings of the First Annual Meeting of the Berkeley Linguistics Society (123-131). Berkeley: Berkeley Linguistics Society.

Fowler, R. \& Kress, G. (1979). Critical linguistics. In R. Fowler, B. Hodge, G. Kress \& T. Trew (Eds.). Language and control (pp. 185-213). London: Routledge.

Gilbert, L. (2013). The Discursive Production of a Mexican Refugee Crisis in Canadian Media and Policy. Journal of Ethnic and Migration Studies, 39(5), 827-843.

Goatly, A. (2007). Discourse approaches to politics, society and culture: Vol. 23. Washing the brain: Metaphor and hidden ideology. Amsterdam: John Benjamins Publishing Company.

Goffman, E. (1974). Frame Analysis. An Essay on the Organization of Experience. Harmondsworth: Penguin Books.

Griffith, A. (2015). Multiculturalism in Canada: Evidence and Anecdote. Washington: Anar Press.

Hagan, J. (2001). Northern Passage: American Vietnam War Resisters in Canada. Massachusetts: Harvard University Press.

Hanson-Easey, S., Augoustinos, M., \& Moloney, G. (2014). 'They're All Tribals': Essentialism, Context and the Discursive Representation of Sudanese Refugees. Discourse \& Society, 25(3), 362-382.

Hart, C. (2011). Force-Interactive Patterns in Immigration Discourse: A Cognitive Linguistic Approach to CDA. Discourse \& Society, 22 (3), 269-286. 
Hier, S. P., \& Greenberg, J, L. (2002). Constructing a discursive crisis: Risk, problematization and illegal Chinese in Canada. Ethnic and Racial Studies, 25(3), 490-513.

Johnston, T. (2016). The Securitization of Refugees: A Critical Media Discourse Analysis of the Reporting on Syrian Refugees in Canada. Unpublished Masters Thesis. Ryerson University, Canada.

Kelly-Gagnon, M., \& Geloso, V. (2013). Who Spends More: Left or Right?. Montreal Economic Institute. Retrieved 19, February 2018 from https://www.iedm.org/sites/default/files/pub_files/note0413_en.pdf

Khosravinik, M. (2009). The Representation of Refugees, Asylum Seekers and Immigrants in British Newspapers During the Balkan Conflict (1999) and the British General Election (2005). Discourse \& Society, 20(4), 477-498.

Khosravinik, M. (2010). The Representation of Refugees, Asylum Seekers and Immigrants in British Newspapers: A critical Discourse Analysis. Journal of Language and Politics, 9(1), 1-28.

KhosraviNik, M. (2014). Immigration Discourses and Critical Discourse Analysis: Dynamics of World Events and Immigration Representations in the British Press. In C. Hart \& P. Cap (Eds.). Contemporary Critical Discourse Studies (pp.501-519). London and New York: Bloomsbury Academic.

Lakoff, G. (2004). Don't Think of an Elephant! Know your values and frame the debate. The essential guide for progressives. Chelsea Green Publishing: Vermont, USA.

Lawton, R. (2013). Speak English or Go Home: The Anti-Immigrant Discourse of the American 'English Only' Movement. Critical Approaches to Discourse Analysis Across Disciplines, 7 (1): $100-122$.

Leudar, I., Hayes, J., Nekvapil, J., \& Baker, T. J. (2008). Hostility Themes in Media, Community and Refugee Narratives. Discourse \& Society, 19(2), 187-221.

Lynn, N., \& Lea, S. (2003). 'A Phantom Menace and the New Apartheid': The Social Construction of Asylum-Seekers in the United Kingdom. Discourse \& Society, 14(4), 425-452.

Mahtani, M. (2001). Representing minorities: Canadian media and minority identities. Canadian Ethnic Studies, 33(3), 99-133.

Matthes, J., \& Kohring, M. (2008).The Content Analysis of Media Frames: Toward Improving Reliability and Validity. Journal of Communication, (58)2, 258-279.

Medianu, S., Sutter, A., \& Esses, V. (2015). The Portrayal of Refugees in Canadian Newspapers: The Impact of the Arrival of Tamil Refugees by Sea in 2010. IdeAs: Idées d'Amériques, (6), 1-15.

Muhammedi, S. (2015). Lessons Learned from the Ugandan Asian Refugees. Active History. Retrieved 12, January 2016 from http://activehistory.ca/2015/09/political-will-publicresources-and-refugee-resettlement-lessons-learned-from-uganda/.

News Media Canada. (2015). Circulation Report: Daily Newspapers 2015. Retrieved 20 July 2019 from https://nmc-mic.ca/wp-content/uploads/2016/06/2015-Daily-NewspaperCirculation-Report-REPORT_FINAL.pdf

Oudshoorn, A., Benbow, S., \& Meyer, M. (2020). Resettlement of Syrian Refugees in Canada. Journal of International Migration and Integration, 21, 893-908.

Parker, S. (2015). 'Unwanted Invaders': The Representation of Refugees and Asylum Seekers in the UK and Australian Print Media. ESharp, (23), 1-21.

Pearce, J. M., \& Stockdale, J. E. (2008). UK Responses to the Asylum Issue: A Comparison of Lay and Expert Views. Journal of Community and Applied Social Psychology, 19(2), $142-155$.

Powell, J. (2005). Encyclopaedia of North American Immigration. New York: Facts on File, Inc. 
Reisigl, M. (2007). Discrimination in Discourse. In H. Kotthoff \& H. Spencer- Oatey (Eds.), Handbook of Intercultural Communication (pp. 365-394). Berlin: Walter De Gruyter Gmbh \& Co.

Reisigl, M., \& Wodak, R. (2009). The discourse-historical approach. In R. Wodak \& M. Meyer (Eds.), Methods of critical discourse analysis (2nd ed., pp. 87-121). London, UK: Sage.

Reitmanova, S., Gustafson, D. L., \& Ahmed, R. (2015). "Immigrants Can Be Deadly": Critical Discourse Analysis of Racialization of Immigrant Health in the Canadian Press and Public Health Policies. Canadian Journal of Communication, 40(3), 471-487.

Ritchie, J., Lewis, J., \& Elam, G. (2003). Designing and Selecting Samples. In Ritchie, J. \& Lewis, J. (Eds.). Qualitative Research Practice A Guide for Social Science Students And Researchers (pp. 77-108). London: SAGE Publications.

Salahshour, N. (2017). Representation of Immigrants in New Zealand Print Media: A critical discourse analysis. Unpublished Doctoral Thesis Victoria University of Wellington, New Zealand. http://researcharchive.vuw.ac.nz/bitstream/handle/10063/6226/thesis.pdf? sequence=1

Samaie, M., \& Malmir, B. (2017). US news media portrayal of Islam and Muslims: a corpusassisted Critical Discourse Analysis. Educational Philosophy and Theory, 49 (14), 116.

Schwöbel-Patel, C., \& Ozkaramanli, D. (2017). The Construction of the 'Grateful' Refugee in Law and Design. Queen Mary Human Rights Law Review, 4(1), 1-10.

Scott, C. \& Safdar, S. (2017). Threat and Prejudice against Syrian Refugees in Canada: Assessing the Moderating Effects of Multiculturalism, Interculturalism, and Assimilation. International Journal of Intercultural Relations, 60, 28-39.

Statistics Canada. (2018). Police-reported hate crime in Canada, 2017. Retrieved 25, May 2019 From https://www150.statcan.gc.ca/n1/pub/11-627-m/11-627-m2018051eng.htm

Stevenson, R. (2005). "Refugees and economic contributions". Hopes fulfilled, or dreams shattered? From resettlement to settlement - Responding to the needs of new and emerging refugee communities conference. University of New South Wales, Sydney, 23-28 November.

Tankard, J. (2001). The Empirical Approach to the Study of Media Framing. In S. D. Reese, O. H. Gandy, A. E. Grant (Eds.), Framing Public Life Perspectives on Media and Our Understanding of the Social World (pp. 95-106). New York: Routledge.

The Government of Canada. (2016a). Canadian Multiculturalism Act R.S.C., 1985, c. 24 (4th Supp.) retrieved 22, February 2017 from https://www.canlii.org/en/ca/laws/stat/rsc1985-c-24-4th-supp/latest/rsc-1985-c-24-4th-supp.html.

The Government of Canada. (2016b). Family violence: How big is the problem in Canada? Retrieved 13, December 2018 from https://www.canada.ca/en/publichealth/services/health-promotion/stop-family-violence/problem-canada.html.

Torma, K. (2017). Refugees in British Media Coverage A Study of Dehumanizing Conceptual Metaphors. Unpublished Bachelors Thesis. Umeå University, Sweden. http://www.diva-portal.org/smash/get/diva2:1113166/FULLTEXT02

Trudeau, J. [Siggy]. (2014, February 11). The budget will balance itself. https://www.youtube.com/watch?v=5VgNEsWx9pI

Trudeau, J. (2015, Aug 12). "Great to talk to people in Regina about our plan to strengthen the heart of the Canadian economy: the middle class" [twitter post]. https://twitter.com/justintrudeau/status/631554513799766016.

Tyyska, V., Blower, J., DeBoer, S., Kawai, S., \& Walcott, A. (2017). The Syrian Refugee Crisis in Canadian Media. RCIS Working Paper. Ryerson University. 
UN News. (2017). Syria "worst man-made disaster since World War II" - UN rights chief. Retrieved February 6, 2018 from https://news.un.org/en/story/2017/03/553252-syriaworst-man-made-disaster-world-war-ii-un-rights-chief.

Venir, A. (2015). UK Media Representation of Syrian Refugees: A Focus on the Press. Retrieved 25, June 2017

from https://www.academia.edu/9283960/UK_Media_Representation_of_Syrian_Refugees A Focus on the Press.

Wallace, R. (2018). Contextualizing the Crisis: The Framing of Syrian Refugees in Canadian Print Media. Canadian Journal of Political Science, 51(02), 207-231.

Wilkinson, L., \& Garcea, J. (2017). The Economic Integration of Refugees in Canada: A Mixed Record?. Immigration Policy Institute. https://reliefweb.int/sites/reliefweb.int/files/resources/TCM-Asylum_CanadaFINAL.pdf

Yaylaci, F. G., \& Karakus, M. (2015). Perceptions and newspaper coverage of Syrian refugees in Turkey. Migration Letters, 12(3), 238-250. 


\section{APPENDIX A List of Selected Articles}

\begin{tabular}{l|ll}
\hline \multicolumn{2}{c}{ The Toronto Star } \\
\hline 1 & T.SR 10, Dec, 15-1 & \multicolumn{1}{c}{ Ontario sponsors greet Syrian refugees with cheers at Pearson } \\
2 & T.SR 12, Dec, 15-3 & Photo-op reception for refugees not just for show: Cohn \\
3 & T.SR 14, Dec, 15-2 & Warm welcome for refugees marks end of era of meanness \\
4 & T.SR 15, Dec, 15-1 & Resettlement of Syrian refugees also pays political dividends: Hébert \\
5 & T.SR 19, Dec, 15-2 & 'Unsung hero' gives hope to two-dozen Syrian refugees \\
6 & T.SR 13, Jan, 16-1 & The toughest part of Syrian resettlement is still ahead: Tim Harper \\
7 & T.SR 13, Jan, 16-2 & Syrian refugees pepper-sprayed in Vancouver still grateful to Canadians \\
8 & T.SR 13, Jan, 16-3 & Syrian refugees now must be integrated into Canadian life, ministers say \\
9 & T.SR 28, Jan, 16-2 & John McCallum 'honoured' to be at helm of Syrian refugee file \\
10 & T.SR 7, Feb, 16-1 & Escaping Syria: From Homs to a new home \\
11 & T.SR 29, Feb, 16-3 & 'This is a terrific day for us:' Immigration Minister on meeting Syrian refugee \\
& & targets \\
12 & T.SR 4, Mar, 16-1 & Smugglers sentenced to 4 years in death of Syrian boy Alan Kurdi \\
13 & T.SR 12, Mar, 16-1 & Syrian refugee play groups provide distraction in long housing wait \\
14 & T.SR 1, Sep, 16-1 & How Alan Kurdi's tragic death changed thousands of lives \\
15 & T.SR 13, Mar, 17-1 & Syrian refugee says family's chocolate business shows value of Canadian \\
& & 'openness' \\
\hline & thePizza12 & \\
\hline & & \multicolumn{1}{c}{ The Toronto Sun } \\
\hline 16 & T.SN 6, Dec, 15-1 & Syrian refugee family building new life in GTA \\
17 & T.SN 11, Mar, 16-1 & Let's help refugees embrace Canada \\
18 & T.SN 25, May 16-1 & Trudeau neglecting Syrian refugees \\
19 & T.SN 10, Jun, 16-1 & McCallum continues to boast as refugee integration stumbles \\
20 & T.SN 6, Jul, 16-1 & Opposing reckless immigration isn't racist \\
21 & T. SN 1, Nov, 16- 1 & Canada's naive about immigrants, Refugees \\
22 & T.SN 25, Nov, 16-1 & The truth about Trudeau's refugee budget numbers \\
& & \\
\hline
\end{tabular}

\begin{tabular}{|c|c|c|}
\hline \multicolumn{3}{|r|}{ The National Post } \\
\hline 23 & NP 1, Dec, 15-1 & $\begin{array}{l}\text { Immigration minister acknowledges threat of backlash if government seen to } \\
\text { pamper Syrian refugees }\end{array}$ \\
\hline 24 & NP 6, Dec, 15-1 & $\begin{array}{l}\text { 'In Syria, people faced us with live bullets': A refugee's long journey to } \\
\text { Canada, in his own words }\end{array}$ \\
\hline 25 & NP 28, Dec, 15-2 & $\begin{array}{l}\text { Matthew Fisher: Time for a reality check on Canada's generosity toward } \\
\text { refugees }\end{array}$ \\
\hline 26 & NP 7, Jan, 16-1 & $\begin{array}{l}\text { Chris Selley: Counterpoint: The Liberals have laid out an ambitious agenda. } \\
\text { Good for them }\end{array}$ \\
\hline 27 & NP 22, Jan, 16-1 & $\begin{array}{l}\text { 'Our housing stock is not strong': Hotels become shelters as } \\
\text { agencies scramble to settle refugees }\end{array}$ \\
\hline 28 & NP 1, Feb, 16-1 & $\begin{array}{l}\text { Small business owners hope Syrian refugees can fill some long vacant } \\
\text { positions }\end{array}$ \\
\hline 29 & NP 8, Mar, 16-1 & $\begin{array}{l}\text { Liberals plan for huge influx of refugees, immigrant spouses at expense of } \\
\text { skilled foreign workers }\end{array}$ \\
\hline 30 & NP 27, Aug, 16-1 & $\begin{array}{l}\text { Waiting for hope: The story of Sham, from war-torn Syria to Saskatoon with } \\
\text { skin as fragile as butterfly wings }\end{array}$ \\
\hline 31 & NP 20, Nov, 16-1 & $\begin{array}{l}\text { Syrian refugees rebuilding their lives in suburban Canada — but many on long } \\
\text { waiting lists for language classes }\end{array}$ \\
\hline
\end{tabular}




\section{ABOUT THE AUTHORS}

Manar Mustafa received her Ph.D. from the International Islamic University Malaysia. Her current research interests are critical discourse analysis, minority groups in the media and discourse and politics.

Zahariah Pilus is an associate professor at the Department of English Language and Literature, International Islamic University Malaysia. She obtained her Ph.D. in Linguistics, from the University of Wisconsin-Madison (USA). Her main research interests include phonetics, language learning and language use in the society. 